\title{
Glycerol Oxidation by Fluorinated and Platinized Titania
}

\section{Oxidación de glicerol mediante titania fluorizada y platinizada}

\author{
E. Bautista ${ }^{1}$, E. G. Ávila-Martínez ${ }^{2}$, R. Natividad ${ }^{1}$, J. J. Murcia ${ }^{2}$, R. Romero ${ }^{1}$, J. Cubillos ${ }^{2}$, J. S. Hernández ${ }^{2}$, \\ O. Cárdenas ${ }^{3}$, M. C. Hidalgo ${ }^{4}$, J. A. Navío ${ }^{4}$, and R. Baeza-Jiménez ${ }^{2}$
}

\begin{abstract}
In this work, fluorinated and platinized $\mathrm{TiO}_{2}$ were evaluated in the glycerol oxidation. Fluorination led to increasing the specific surface area of titania, and platinization treatment to obtaining the highest absorption in the visible region of the electromagnetic spectrum; thus, $0.5 \mathrm{wt} \% \mathrm{Pt}-\mathrm{F}-\mathrm{TiO}_{2}$ was the best catalyst for its highest yield and good selectivity to glyceraldehyde (GAL). It was also found that $2 \mathrm{wt} \%$ of Pt content had a detrimental effect on the glycerol conversion. Fluorination and platinum addition led to modify the reaction mechanism and selectivity.
\end{abstract}

Keywords: glycerol, 0.5 wt \% Pt-F-TiO $2,2 \mathrm{wt} \%$ Pt-F-TiO ${ }_{2}$, glyceraldehyde, dihydroxyacetone

\section{Resumen}

En este trabajo se evaluó el $\mathrm{TiO}_{2}$ fluorado y platinizado en la oxidación de glicerol. La fluoración condujo al aumento de la superficie específica de titania y el tratamiento de platinización a obtener la mayor absorción en la región visible del espectro electromagnético; por tanto, $0,5 \%$ en peso de Pt-F-TiO ${ }_{2}$ fue el mejor catalizador por su rendimiento más alto y buena selectividad para gliceraldehído (GAL). También se encontró que el $2 \%$ en peso del contenido de Pt tenía un efecto perjudicial sobre la conversión de glicerol. La fluoración y la adición de platino llevaron a modificar el mecanismo de reacción y la selectividad.

Palabras clave: glicerol, 0,5\% en peso de $\mathrm{Pt}-\mathrm{F}-\mathrm{TiO}_{2}, 2 \%$ en peso de $\mathrm{Pt}-\mathrm{F}-\mathrm{TiO}_{2}$, gliceraldehído, dihidroxiacetona

Recepción: 15-jul-2020

Aceptación: 31 -oct-2020

\footnotetext{
${ }^{1}$ Centro Conjunto de Investigación en Química Sustentable UAEM-UNAM-México

${ }^{2}$ Grupo de Catálisis, Escuela de Ciencias Químicas, Universidad Pedagógica y Tecnológica de Colombia UPTC. Corresponding author e-mail: julie.murciaeuptc.edu.co

${ }^{3}$ Grupo de Fisicoquímica molecular y modelamiento computacional, Escuela de Ciencias Químicas, Universidad Pedagógica y Tecnológica de Colombia

${ }^{4}$ Instituto de Ciencia de Materiales de Sevilla (ICMS), Consejo Superior de Investigaciones Científicas CSIC, Universidad de Sevilla
} 


\section{Introduction}

Currently, the excess of glycerol coming from biodiesel industry represents a serious problem, so to develop innovative applications to utilize this compound is a serious challenge for scientific community. Some authors have reported successful studies on this topic. Pagliaro et al., for example, have described the production of 1,3-dihydroxyacetone and hydroxypyruvic acid by glycerol oxidation and the improvement of cements by bioglycerol addition. Kenar [3] also has reported the obtention of different organic compounds from glycerol partial oxidation.

The main catalysts of interest for glycerol oxidation appear to focus on carbon-supported $\mathrm{Pt}, \mathrm{Pd}$ or $\mathrm{Au}$ and bimetallic catalysts such as Au-Pd and Au$\mathrm{Pt}$ [4]. As a result of the use of aqueous glycerol solutions as raw material, glyceric acid, dihydroxyacetone, tartronic acid, and hydroxypyruvic acid have been reported as the main reaction byproducts [5]. These results depend on different properties of the catalysts employed such as particle size and on the reaction conditions; thus, Ketchie et al. have shown the highest selectivity to glyceric acid by using a $1 \mathrm{wt} \% \mathrm{Au}(5-50 \mathrm{~nm}) /$ graphite materials [6].

In the present work, $\mathrm{TiO}_{2}$ has been tested for glycerol oxidation, as the strategies for improve the oxidizing power and physicochemical properties of this oxide, fluorination and incorporation of platinum nanoparticles were employed.

Titania is a well-known material employed in different eco-friendly processes, this is because of its stability, strong oxidizing power and relative low cost [7-16]. In order to improve the properties of $\mathrm{TiO}_{2}$, metal doping, fluorination and sulfation are suitable alternatives for increasing the specific surface area and the absorption of the oxide in the visible region of the electromagnetic spectrum [7, $12,13]$.

\section{Methodology}

\subsection{Catalysts preparation}

\subsection{1 $\mathrm{TiO}_{2}$}

Hydrolysis of $200 \mathrm{~mL}$ of titanium tetraisopropoxide (Aldrich, 97\%) in isopropanol solution (1.6 M) was achieved by distilled water addition (isopropanol:water 1:1, V/V). The material obtained was labeled as $\mathrm{sg}-\mathrm{TiO}_{2}$. It was recovered by filtration, drying at $110^{\circ} \mathrm{C}$ overnight and calcination at $650{ }^{\circ} \mathrm{C}$ for $2 \mathrm{~h}, 4^{\circ} \mathrm{C} / \mathrm{min}$ was employed as the heating rate.

Commercial $\mathrm{TiO}_{2} \mathrm{P} 25$ Evonik $\left(\mathrm{TiO}_{2}(\mathrm{C})\right)$ was employed as the reference material with no additional treatment.

\subsection{2 $\quad \mathrm{F}-\mathrm{TiO}_{2}$}

Fluorinated $\mathrm{TiO}_{2}\left(\mathrm{~F}-\mathrm{TiO}_{2}\right)$, was obtained from an aqueous suspension of fresh $\mathrm{sg}-\mathrm{TiO}_{2}(2 \mathrm{~g})$ in $1 \mathrm{~L}$ of $10 \mathrm{mM} \mathrm{NaF}$ solution; the $\mathrm{pH}$ was adjusted to 3 by using a solution $1 \mathrm{M}$ of $\mathrm{HCl}$ (in order to improve the fluoride adsorption) [12,13]; this suspension was maintained in the dark under continuous stirring for $1 \mathrm{~h}$. The powders were recovered by filtration, dried and calcined at $650{ }^{\circ} \mathrm{C}$ for $2 \mathrm{~h}, 4^{\circ} \mathrm{C} / \mathrm{min}$ was used as the heating rate.

\subsubsection{Pt addition}

Platinum addition was carried out by using Hexachloroplatinic acid $\left(\mathrm{H}_{2} \mathrm{PtCl}_{6}\right.$, Aldrich $\left.99.9 \%\right)$ as the metal precursor. For this procedure, a suspension of the $\mathrm{F}_{-}-\mathrm{TiO}_{2}$ sample in distilled water containing $0.3 \mathrm{M}$ of isopropanol (Merck 99.8\%) was employed. The necessary amount of metal precursor to obtain nominal Pt loading of 0.5 and $2 \mathrm{wt} \%$ on $\mathrm{TiO}_{2}$ was added to this suspension. Metal photodeposition was performed under $\mathrm{N}_{2}$ flux $(0.90 \mathrm{~L} / \mathrm{h})$, under illumination for $120 \mathrm{~min}$. Light intensity on the suspension was $60 \mathrm{~W} / \mathrm{m}^{2}$ measured by using a photo-radiometer Delta OHM, HD2102.1. An Osram Ultra-Vitalux lamp $(300 \mathrm{~W})$ was used as the light source, with a main emission line in the UVA range at $365 \mathrm{~nm}$. The materials obtained were recovered by filtration and dried at $110{ }^{\circ} \mathrm{C}$ for $12 \mathrm{~h}$. These materials were labeled as $0.5 \mathrm{Pt}-\mathrm{F}-\mathrm{TiO}_{2}$ and $2 \mathrm{Pt}-\mathrm{F}-\mathrm{TiO}_{2}$. 


\subsection{Catalysts characterization}

The study of catalysts prepared was carried out by using different analytic techniques such as: TEM, $\mathrm{S}_{B E T}$, XRD, UV-Vis DR spectrophotometry, $\mathrm{XRF}$ and XPS. The analysis parameters have been extensively reported at $[12,13]$.

\subsection{Catalytic reactions}

Glycerol oxidation was carried out in an open glass cylindrical reactor $(2 \mathrm{~cm} \mathrm{ID,} 20 \mathrm{~cm}$ height) fitted with a cooling jacket. A $8 \mathrm{~W}$ lamp provided the UV light inside the reactor with a main emission at $254 \mathrm{~nm}$, the energy source was a UVP PS-1 of $115 \mathrm{~V} / 60 \mathrm{~Hz}$ and $40 \mathrm{~A}$. All the catalytic tests were carried out in batch mode under continuous stirring. A suspension of the catalysts $\left(\mathrm{TiO}_{2}(\mathrm{C})\right.$, sg$\mathrm{TiO}_{2}, \mathrm{~F}-\mathrm{TiO}_{2}, 0.5 \mathrm{Pt}-\mathrm{F}-\mathrm{TiO}_{2}$ and $2 \mathrm{Pt}-\mathrm{F}-\mathrm{TiO}_{2}$ ) in $100 \mathrm{~mL}$ of an aqueous glycerol (J. T. Baker, 99.7\%) solution $(100 \mathrm{mM})$ was prepared. The open reactor led the presence of natural room oxygen, room temperature $\left(19^{\circ} \mathrm{C}\right)$ and a starting $\mathrm{pH}$ value of 7.8 were employed in all the reactions and the reaction conditions evaluated were: Pt loading ( 0.5 and $2 \mathrm{wt} \%)$ and catalyst amount (10, 30 and $40 \mathrm{mg})$. Blank tests without catalytic materials were also performed. All the reactions were performed by duplicate.

At the end of each reaction cycle, $90 \%$ of the catalysts were recovered by filtration $(0.45 \mu \mathrm{m}$ filter $)$.

\subsection{Reaction products determination}

$1.5 \mathrm{~mL}$ were sampled from the reactor at $0,5,10,15$, $30,60,120,180,240$ and $300 \mathrm{~min}$, then, these samples were filtered (Sartorius Biolab filters with a pore size of $0.45 \mu \mathrm{m}$ ) and analyzed by High Performance Liquid Chromatography (HPLC) and Total Organic Carbon (TOC). The analytic parameters employed in these techniques are described as follows:

HPLC: $20 \mu \mathrm{L}$ of each sample were injected in a SHIMADZU Model LC-2030 chromatograph by using an UV $210 \mathrm{~nm}$ detector, a SiliaChrom SB C18 column (250 mm length $\mathrm{x} 5 \mathrm{~mm}$ internal diameter x $5 \mu \mathrm{m}$ Film thickness), $45^{\circ} \mathrm{C}$, an aqueous solution $0.01 \mathrm{mM}$ of $\mathrm{H}_{2} \mathrm{SO}_{4}$ was employed as mobile phase, flow rate of $0.5 \mathrm{~mL} / \mathrm{min}$ and total elution time of 10 $\min$.

HPLC standards: Aqueous solutions of Glycerol (G) J. T. Baker, 99.7\%, Glyceraldehyde (GAL) Sigma-Aldrich, $>90 \%$, Dihydroxyacetone (DHA) Sigma-Aldrich 97\%, Glycolic acid (GA) SigmaAldrich, $70 \mathrm{wt} \%$ in water, and Formic acid (FA) Honeywell $>98 \%$.

The concentration of reactive and by products was determined by integration of the data by using the Prominence I de SHIMADZU Labsolutions software. Robustness, precision and accuracy studies were performed; from this calculation it was possible to found a variation coefficient lower than $2 \%$, showing the reliability of the measurements. The next equations were employed to determine the glycerol conversion, yield and selectivity:

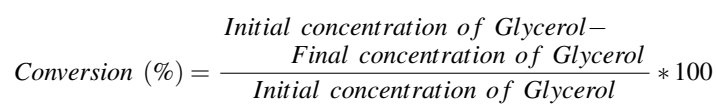

$$
\text { Yield }(\%)=\frac{\text { Product concentration }}{\text { Initial concentration of Glycerol }} * 100
$$

$$
\text { Selectivity }(\%)=\frac{\text { Yield }}{\text { Glycerol conversion }} * 100
$$

TOC: $100 \mu \mathrm{L}$ of each sample were injected in an Analytikjena Multi N/C 2100/1 equipment, by using a furnace temperature of $750{ }^{\circ} \mathrm{C}$. Each sample was measured by triplicate and the average value was considered. Catalysts recycling analyzes were not carried out because the low catalyst loading employed (10, 30 or $40 \mathrm{mg}$ ); representing the loss of almost $10 \%$ of catalyst in each test, makes nonviable this kind of experiments.

\section{Results and discussion}

\subsection{Physicochemical properties from the cata- lysts characterization}

The results from catalysts characterization have been previously reported $[12,13]$, so, a summary of the more relevant results is presented as follows.

Pt nanoparticle sizes: Selected TEM images of Pt-F-TiO ${ }_{2}$ catalysts are presented in Figure 1, 
where platinum particles appear as small black spots, which are heterogeneously distributed, with zones presenting many particles and other empty zones on $\mathrm{TiO}_{2}$ surface. The average particle size has been previously reported of $6 \mathrm{~nm}[12,13]$ and over 7 $\mathrm{nm}$ for the $0.5 \mathrm{Pt}-\mathrm{F}-\mathrm{TiO}_{2}$ and $2 \mathrm{Pt}-\mathrm{F}-\mathrm{TiO}_{2}$ catalysts, respectively; $\mathrm{Pt}$ nanoparticles in the sample with 2 wt\% of platinum content $\left(2 \mathrm{Pt}-\mathrm{F}-\mathrm{TiO}_{2}\right)$ show the highest particles aggregation.
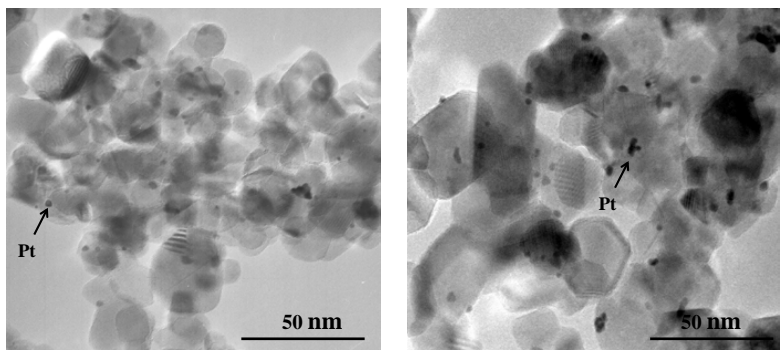

Figure 1. Selected TEM images of $\mathrm{Pt}-\mathrm{F}-\mathrm{TiO}_{2}$ catalyst. 0.5 Pt-F-TiO 2 (a) and 2 Pt-F-TiO 2 (b).

Specific surface area: In Table 1 it is possible to observe that the lowest value for specific surface area $\left(\mathrm{S}_{B E T}\right)$ corresponds to $11 \mathrm{~m}^{2} / \mathrm{g}$ in the $\mathrm{sg}-\mathrm{TiO}_{2}$ sample, due to titania particles sintering which occurs during the calcination of the bare material. On the contrary, after fluorination, the $\mathrm{S}_{B E T}$ value considerably increases to $51 \mathrm{~m}^{2} / \mathrm{g}$, thus showing the protective effect of the fluorine ions over the $\mathrm{S}_{B E T}$ $\mathrm{TiO}_{2} \mathrm{~S}_{B E T}$ at high temperature [8]. Specific surface area of $\mathrm{F}_{-} \mathrm{TiO}_{2}$ slightly decreases after Pt addition, thus indicating the obstruction of $\mathrm{TiO}_{2}$ surface by platinum nanoparticles; this effect is less evident in the catalyst with 2 wt $\%$ of Pt loading, where the higher Pt size particles produces less obstruction of $\mathrm{F}-\mathrm{TiO}_{2}$ surface.

Table 1. Characterization results summary

\begin{tabular}{lccccc}
\hline Materials & $\begin{array}{c}\text { Specific surface } \\
\text { area }\left(\mathbf{m}^{2} / \mathbf{g}\right)\end{array}$ & $\begin{array}{c}D_{\text {Anatase }}(\mathbf{n m}) \\
\end{array}$ & & Band gap (eV) & \multicolumn{2}{c}{$\begin{array}{c}\text { Binding } \\
\text { energy }(\mathbf{e V})\end{array}$} \\
\hline $\mathrm{TiO}_{2}(\mathrm{C})$ & 51 & 22 & 3.23 & 458.5 & 529.8 \\
$\mathrm{sg}^{-\mathrm{TiO}_{2}}$ & 11 & 17 & 3.30 & 458.5 & 529.8 \\
$\mathrm{~F}_{2}-\mathrm{TiO}_{2}$ & 51 & 24 & 3.21 & 458.4 & 529.6 \\
$0.5 \mathrm{Pt}-\mathrm{F}-\mathrm{TiO}_{2}$ & 42 & 23 & 3.24 & 458.3 & 529.6 \\
$2 \mathrm{Pt}-\mathrm{F}-\mathrm{TiO}_{2}$ & 50 & 22 & 3.26 & 461.3 & 531.2 \\
\hline
\end{tabular}

Crystalline phases: Rutile and anatase with a ratio of 90/10 are present in the $\mathrm{TiO}_{2}$ (C) and sg-TiO samples, these crystalline phases are identified by the main XRD peaks located at $25.25^{\circ}$ (JCPDS card no. 21-1272) and $27.44^{\circ}$ (JCPDS card no. 21-1276), respectively (Figure 2).

Rutile phase formation takes place in the sg$\mathrm{TiO}_{2}$ sample by titania particles sintering during the calcination at high temperature, which is also associated with the lowest specific surface area observed in this material. In the fluorinated and platinized samples, the fluorine ions protect the titania surface and therefore only anatase phase of $\mathrm{TiO}_{2}$ was identified, which is in agreement with previous reported results $[11,18]$.

The lowest anatase crystallite size value corresponds to $17 \mathrm{~nm}$ in sg-TiO ${ }_{2}$ sample (Table 1), also due to the particle sintering and formation of Rutile phase in this catalyst $[12,13]$. On the other hand, fluorinated $\mathrm{TiO}_{2}$ presents the highest anatase crystallite size due to the presence of fluoride, which can enhance the crystallization of anatase phase and promote the growth of its crystallites [11,18]. Pt addition did not modify significantly the anatase crystallite size.

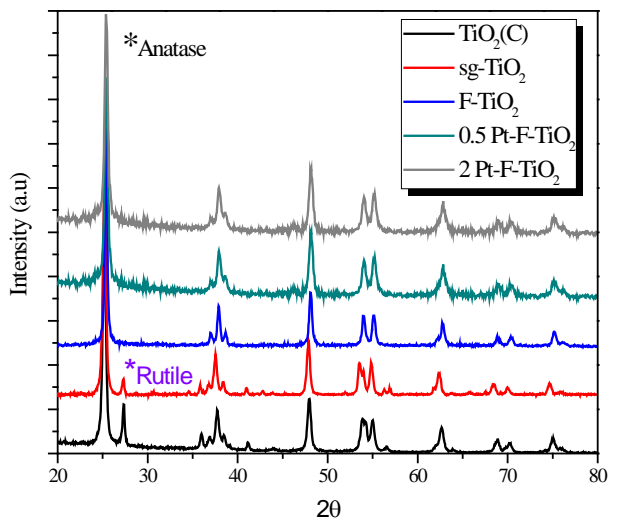

Figure 2. XRD analysis for commercial, lab prepared and modified $\mathrm{TiO}_{2}$.

Optical properties: The absorption band edge of the $\mathrm{TiO}_{2}$ is observed in Figure 3 around $400 \mathrm{~nm}$ for all the materials analyzed. Due to the presence of fluoride species $\left(\mathrm{Ti} \equiv \mathrm{F}\right.$ ) on $\mathrm{TiO}_{2}$ surface, the UV-Vis absorption of the fluorinated samples is slightly higher than that of the $\mathrm{sg}-\mathrm{TiO}_{2}$ material. It was also observed that metallization leads to an increase in absorption in the visible range of the electromagnetic spectrum, due to the grey color of $\mathrm{Pt}-\mathrm{F}-\mathrm{TiO}_{2}$ materials. 
The band gap energies are reported in Table 1, which are between 3.21 and $3.26 \mathrm{eV}$, very close to that of anatase $\mathrm{TiO}_{2}(3.20 \mathrm{eV})$.
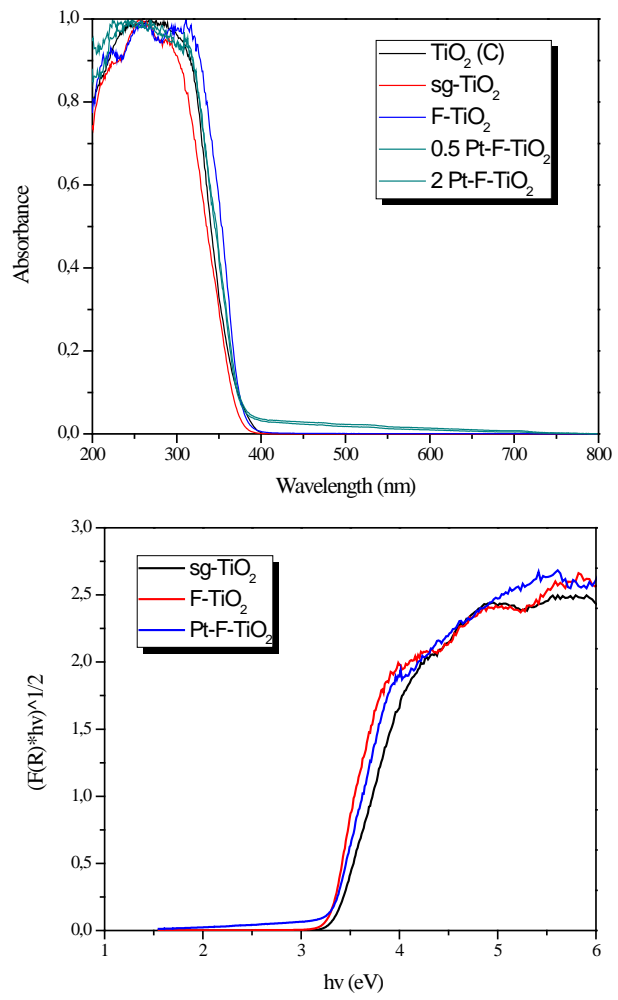

Figure 3. UV-Vis DR spectra of materials prepared.

Chemical content: In the materials analyzed it was possible to detect traces of $\mathrm{Cl}^{-}$species $(0.02 \%)$ from the metal precursor $\left(\mathrm{H}_{2} \mathrm{PtCl}_{6}\right)$. The $\mathrm{Pt}$ content values are lower than the nominal metal loading, thus indicating an incomplete reduction of the metal on the $\mathrm{TiO}_{2}$ surface during the synthesis process. The real Pt content in the samples was close to 0.39 and $1.25 \mathrm{wt} \%$ in the $0.5 \mathrm{Pt}-\mathrm{F}-\mathrm{TiO}_{2}$ and $2 \mathrm{Pt}-\mathrm{F}-\mathrm{TiO}_{2}$, respectively.

XPS: The Ti $2 p$ core peaks presents for all the catalysts the main component at $458.5 \pm 0.1 \mathrm{eV}$ (Ti $2 \mathrm{p}_{3 / 2}$ ), which is typical of the $\mathrm{Ti}^{4+}$ ions in the $\mathrm{TiO}_{2}$ lattice; no modifications were observed after $\mathrm{Pt}$ addition. A peak at $529.8 \pm 0.2 \mathrm{eV}$ is assigned to oxygen atoms in the $\mathrm{TiO}_{2}$ lattice, surface $\mathrm{OH}$ groups were also identified in the $\mathrm{O} 1 \mathrm{~s}$ region by a shoulder at higher binding energy.

Reduced and oxidized Pt species were detected in the platinized samples, as it is represented in Figure 4.

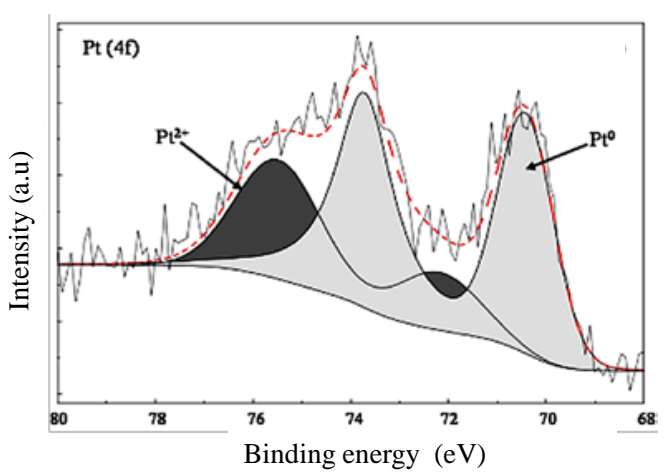

Figure 4. XPS spectra of the region Pt4f in platinized catalysts analyzed.

\subsection{Catalytic performance}

Firstly, tests without illumination and in presence of a catalyst were carried out and no products were observed, but a slight decrease in the glycerol concentration was observed due to the adsorption of this compound in the catalyst surface.

The highest glycerol transformation was observed in the blank test performed without catalyst, the final glycerol concentration after $300 \mathrm{~min}$ of reaction was $11.4 \mathrm{mM}$, obtaining 8 by-products. G, DHA, GAL and FA concentrations, glycerol conversion, and yield and selectivity of the products are summarized in Table 2.

Figure 5 represents the glycerol concentration as a function of the reaction time over each catalyst. The lowest glycerol transformation (i.e. $79.3 \mathrm{mM}$ ) was obtained by using $2 \mathrm{Pt}-\mathrm{F}-\mathrm{TiO}_{2}$ as catalyst.

On the other hand, it was observed that under illumination and in the presence of a catalyst, the glycerol reaction mechanism can be modified. By using sg- $\mathrm{TiO}_{2}$ or commercial $\mathrm{TiO}_{2}$ the glycerol is transformed into FA at the first 15 min of reaction, then, DHA and other compounds are produced. When $\mathrm{F}^{-\mathrm{TiO}_{2}}$ is employed as catalyst only DHA and FA were produced; with platinized catalyst also GAL is produced.

As it can be seen in Table 2, the highest glycerol (i.e. $88.4 \%$ ) takes place in the blank test. The highest yields for GAL and DHA, were achieved with 0.5 Pt-F-TiO 2 catalyst. 
Table 2. Conversion, yield and selectivity in Glycerol oxidation reaction. Total reaction time of $300 \mathrm{~min}$

\begin{tabular}{|c|c|c|c|c|c|c|c|c|c|}
\hline \multirow{2}{*}{ Materials tested } & \multirow{2}{*}{ Glycerol conversion $(\%)$} & \multicolumn{4}{|c|}{ Yield (\%) } & \multicolumn{4}{|c|}{ Selectivity (\%) } \\
\hline & & GAL & DHA & FA & Other products & GAL & DHA & FA & Other products \\
\hline Photolysis & 88.40 & 0.12 & 6.60 & 12.80 & 68.90 & 0.13 & 7.51 & 14.50 & 77.90 \\
\hline linewidth $\mathrm{TiO}_{2}(\mathrm{C})(10 \mathrm{mg})$ & 82.20 & 0.00 & 15.20 & 12.90 & 54.00 & 0 & 18.50 & 15.80 & 65.70 \\
\hline linewidth $\mathrm{sg}-\mathrm{TiO}_{2}(10 \mathrm{mg})$ & 83.50 & 0.00 & 15.16 & 21.24 & 54.7 & 0 & 16.64 & 23.31 & 49.87 \\
\hline linewidth $\mathrm{F}^{-\mathrm{TiO}_{2}}(10 \mathrm{mg})$ & 69.40 & 0.00 & 9.23 & 60.20 & 0 & 0 & 13.30 & 87.00 & 0 \\
\hline linewidth $0.5 \mathrm{Pt}-\mathrm{F}-\mathrm{TiO}_{2}(10 \mathrm{mg})$ & 57.40 & 30.40 & 24.91 & 2.10 & 0 & 52.98 & 43.39 & 3,63 & 0 \\
\hline linewidth 2 Pt-F-TiO $2(10 \mathrm{mg})$ & 20.40 & 12.03 & 0 & 8.33 & 0 & 59.10 & 0 & 40.83 & 0 \\
\hline linewidth $0.5 \mathrm{Pt}-\mathrm{F}-\mathrm{TiO}_{2}(30 \mathrm{mg})$ & 34.11 & 15.45 & 8,60 & 10.10 & 0 & 45.32 & 25.16 & 29.51 & 0 \\
\hline linewidth $0.5 \mathrm{Pt}-\mathrm{F}-\mathrm{TiO}_{2}(40 \mathrm{mg})$ & 14.83 & 14.83 & 0 & 0 & 0 & 0 & 0 & 0 & 0 \\
\hline
\end{tabular}

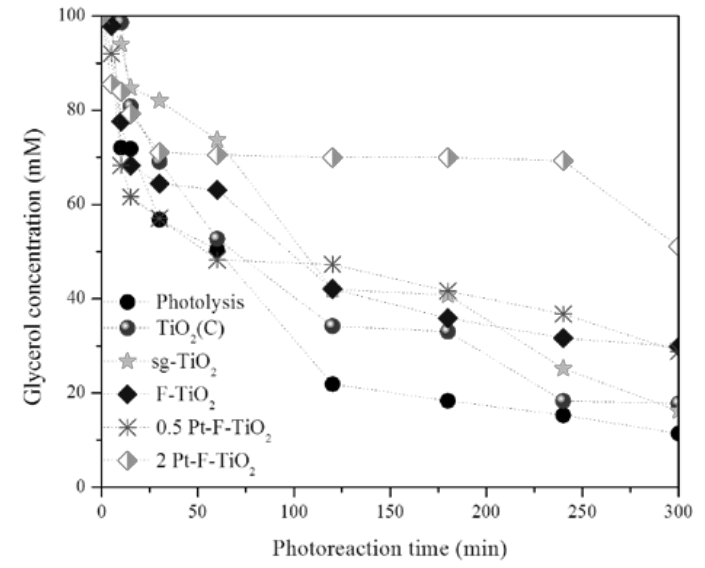

Figure 5. Glycerol concentration evolution over the materials analyzed.

An intermittent behavior was observed over platinized materials, where glycerol concentration increases and then decreases, which can be due to a highest reactive surface, so, glycerol oxidation can be a reversible reaction. This behavior can be explained taking into account that in platinized materials coexist reduced and oxidized Pt species, as it was identified by XPS; these species can define the course of the reaction acting as active sites.

\subsection{Effect of the Pt content}

Figure 6 shows the evolution of the glycerol oxidation products as a function of reaction time over the catalysts analyzed. It is observed that fluorination and $\mathrm{Pt}$ addition on $\mathrm{TiO}_{2}$ decrease glycerol conversion, but Pt significantly increases the yield to GAL and DHA (Table 2), which very important taking into account the potential applications of these compound at industrial level $[2,19,20]$. It is important to note that in the present work by $\mathrm{F}$ and $\mathrm{Pt}$ addition to $\mathrm{TiO}_{2}$ it was possible to increase the selectivity, thus leading to obtain a minor number of byproducts, compared with previous results reported by other authors using different catalytic materials [5].

It is also observed that the Pt loading has an important role in the effectiveness of the $\mathrm{F}-\mathrm{TiO}_{2}$ for glycerol oxidation reaction. By using the $0.5 \mathrm{Pt}-\mathrm{F}-$ $\mathrm{TiO}_{2}$ catalyst, a glycerol conversion of $57.40 \%$, and a yield of 30.40, 24.91 and 2.1 to GAL, DHA and FA, respectively, were obtained. On the other hand, by using $2 \mathrm{Pt}-\mathrm{F}-\mathrm{TiO}_{2}$, both the conversion and yield to the products significantly decreases. This can be due to the glycerol adsorption on catalyst surface, thus, it is possible that $\mathrm{Pt}^{\delta+}$ species can favor the adsorption of glycerol molecule.

As it was observed by TEM, Pt particle size is related with metal loading, and the catalyst presenting the bigger Pt nanoparticles (2 Pt-F-TiO $)$ led to the lowest glycerol transformation. Liang et al. [21] have found that bigger sized Pt particles $(>10 \mathrm{~nm})$ were less active, whereas smaller sized ones $(<6 \mathrm{~nm})$ exhibited higher glycerol conversion and stable selectivity.

\subsection{Effect of the catalyst loading}

The results obtained by using different catalyst amount (i.e. 10,30 and $40 \mathrm{mg}$ ) in the glycerol oxidation reaction over $0.5 \mathrm{Pt}-\mathrm{F}-\mathrm{TiO}_{2}$ catalyst are presented in Table 2. It was observed that glycerol 
conversion and yield to the GAL, DHA and FA decreases as the catalyst loading increases, this behavior is due to a screening effect, which masks part of the photosensitive area inside the reactor, thus reducing the effectiveness of the process in the glycerol oxidation reaction.
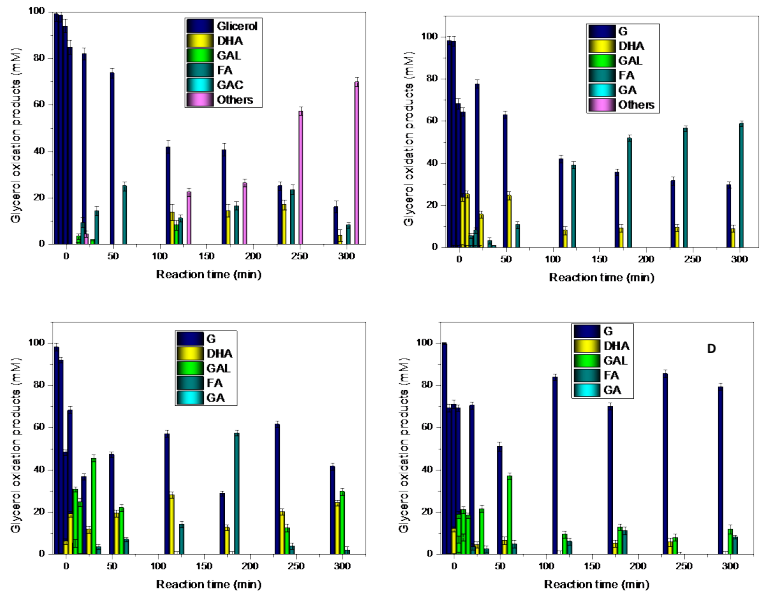

Figure 6. Glycerol and oxidation products concentration as a function of the catalytic oxidation time. (A) sg- $\mathrm{TiO}_{2}$; (B) $\mathrm{F}_{-} \mathrm{TiO}_{2}$; (C) $0.5 \mathrm{Pt}-\mathrm{F}-\mathrm{TiO}_{2}$ and (D) $2 \mathrm{Pt}-\mathrm{F}-$ $\mathrm{TiO}_{2}$.

\subsection{Mineralization}

All the glycerol oxidation reactions were monitored by the Total Organic Carbon (TOC) analyzes, from this technique it was observed that $\mathrm{CO}_{2}$ or $\mathrm{H}_{2}$ did not produced in any of the reactions performed, so, the mineralization was never reached.

\section{Conclusions}

Glycerol can be transformed under illumination producing eight different compounds, but, when a catalyst based on $\mathrm{TiO}_{2}$ is added to reaction medium, the number of products significantly decreases.

Fluorination and platinization are treatments that can modify the physical properties of $\mathrm{TiO}_{2}$ prepared by sol-gel method, thus, a high absorption in the visible region of the electromagnetic spectrum and high surface area are obtained.

It was also observed that fluorine ions and $\mathrm{Pt}$ nanoparticles have an important role in the reaction mechanism and selectivity during glycerol oxidation.
The general behavior in glycerol oxidation can be summarized as follows: (i) the use of commercial or lab prepared $\mathrm{TiO}_{2}$ as catalysts led to three intermediaries products after 60 minutes of reaction; (ii) fluorine addition on $\mathrm{TiO}_{2}$ surface, led to the formation of DHA and FA; (iii) when Pt was added to $\mathrm{F}_{-}-\mathrm{TiO}_{2} \mathrm{GAL}$, DHA and FA were produced.

By increasing the $\mathrm{Pt}$ loading from 0.5 to $2 \mathrm{wt} \%$ glycerol conversion and the intermediaries products yield decrease; it can be related to the better adsorption of glycerol on $0.5 \mathrm{wt} \% \mathrm{Pt}-\mathrm{F}-\mathrm{TiO}_{2}$ catalyst.

$10 \mathrm{mg}$ was the best loading for glycerol oxidation over $0.5 \mathrm{wt} \% \mathrm{Pt}-\mathrm{F}-\mathrm{TiO}_{2}$, this amount is enough to avoid the screening effect inside the reactor.

\section{Acknowledgments}

Authors thanks to Universidad Autónoma del Estado de México (UAEM), grant number 3892/2015 FS, this work was also financed by Fondo Nacional de Financiamiento para la Ciencia, la Tecnología y la Innovación Francisco José de Caldas-Colciencias, Project 279-2016, and Universidad Pedagógica y Tecnológica de Colombia project SGI 2006.

\section{References}

[1] M. Rossi, C. Della-Pina, M. Pagliaro, R. Ciriminna, P. Forni, "Greening the Construction Industry: Enhancing the Performance of Cements by Adding Bioglycerol", Chem. Sus. Chem., 1, p. 809-812, 2008.

[2] R. Ciriminna, G. Palmisano, C. Della-Pina, M. Rossi, M. Pagliaro, "One-pot electrocatalytic oxidation of glycerol to DHA", Tetrahedron Lett., 47, p. 6993-6995, 2006.

[3] J.A. Kenar, "Glycerol as a platform chemical: Sweet opportunities on the horizon?", Lipid Technol., 19, p. 249-253, 2007.

[4] M. Bowker, C. Morton, J. Kennedy, H. Bahruji, J. Greves, W. Jones, P. R. Davies, C. P. Brookes, P. Wells, N. Dimitratos, "Hydrogen production by photoreforming of biofuels using $\mathrm{Au}, \mathrm{Pd}$ and $\mathrm{Au}-\mathrm{Pd} / \mathrm{TiO}_{2}$ photocatalysts", J. Catal., 310, p. 10-15, 2014. 
[5] S. Demirel-Gülen, M. Lucas, P. Claus, "Liquid phase oxidation of glycerol over carbon supported gold catalysts" Catal. Today., 102, p. 166-172, 2005.

[6] W. C. Ketchie, M. Murayama, R. J. Davis, "Selective oxidation of glycerol over carbonsupported AuPd catalysts", J. Catal., 250, p. 264-273, 2007.

[7] M. Maicu, M. C. Hidalgo, G. Colón, J. A. Navío, "Comparative study of the photodeposition of $\mathrm{Pt}, \mathrm{Au}$ and $\mathrm{Pd}$ on pre-sulphated $\mathrm{TiO}_{2}$ for the photocatalytic decomposition of phenol", J. Photochem. Photobiol., A., 217, p. 275-283, 2011.

[8] D. Li, H. Haneda, S. Hishita, N. Ohashi, N.K. Labhsetwar, "Fluorine-doped $\mathrm{TiO}_{2}$ powders prepared by spray pyrolysis and their improved photocatalytic activity for decomposition of gas phase acetaldehyde", J. Fluorine Chem., 126, p. 69-77, 2005.

[9] K. Okazaki, Y. Morikawa, S. Tanaka, K. Tanaka, M. Kohyama, "Effects of stoichiometry on electronic states of Au and Pt supported on $\mathrm{TiO}_{2}(110) "$, J. Mater. Sci. 40, p. 3075-3080, 2005.

[10] J. J. Murcia, J. R. Guarín, A. C. Cely Macías, H. Rojas, J. A. Cubillos, M. C. Hidalgo, J. A. Navío, "Methylene blue degradation over M$\mathrm{TiO}_{2}$ photocatalysts $(\mathrm{M}=\mathrm{Au}$ or Pt)", Ciencia en Desarrollo, 8, p. 109-117, 2017.

[11] J. Yu, Q. Xiang, J. Ran, S. Mann, “One-step hydrothermal fabrication and photocatalytic activity of surface-fluorinated $\mathrm{TiO}_{2}$ hollow microspheres and tabular anatase single microcrystals with high-energy facets", Cryst. Eng. Commun., 12, p. 872-879, 2010.

[12] J. J. Murcia, M. C. Hidalgo, J. A. Navío, J. Araña, J. M. Doña-Rodríguez, "Study of the phenol photocatalytic degradation over $\mathrm{TiO}_{2}$ modified by sulfation, fluorination, and platinum nanoparticles photodeposition", $A p$. Catal., B., 179, p. 305-312, 2015.
[13] G. Iervolino, V. Vaiano, J. J. Murcia, L. Rizzo, G. Ventre, G. Pepe, P. Campiglia, M. C. Hidalgo, J. A. Navío, D. Sannino, "Photocatalytic hydrogen production from degradation of glucose over fluorinated and platinized $\mathrm{TiO}_{2}$ catalysts", J. Catal., 339, p. 47-56, 2016.

[14] M. N. Chong, V. Vimonses, S. Lei, B. Jin, C. Chow, C. Saint, "Synthesis and characterisation of novel titania impregnated kaolinite nano-photocatalyst", Micropor Mesopor Mat., 117, p. 233-242, 2009.

[15] J. Fernández, J. Kiwi, J. Baeza, J. Freer, C. Lizama, H. D. Mansilla, "Orange II photocatalysis on immobilised $\mathrm{TiO}_{2}$ : Effect of the $\mathrm{pH}$ and $\mathrm{H}_{2} \mathrm{O}_{2}$ ", Ap. Catal. B, 48, p. 205-211, 2004.

[16] R. Molinari, F. Pirillo, M. Falco, V. Loddo, L. Palmisano, "Photocatalytic degradation of dyes by using a membrane reactor", Chem. Eng. Process, 43, p. 1103-1114, 2004.

[17] S. P. Tandom, J. P. Gupta, "Measurement of forbidden energy gap of semiconductors by diffuse reflectance technique", Physica Status Solidi B. 38, p. 363-367, 1970.

[18] M. S. Vohra, S. Kim, W. Choi, "Effects of surface fluorination of $\mathrm{TiO}_{2}$ on the photocatalytic degradation of tetramethylammonium", J. Photochem. Photobiol., A., 160, p. 55-60, 2003.

[19] A. Behr, J. Eilting, K. Irawadi, J. Leschinski, F. Lindner, "Improved utilisation of renewable resources: new important derivatives of glycerol", Green Chem., 10, p. 13-30, 2008.

[20] V. Augugliaro, H. A. Hamed, V. Loddo, A. Mele, G. Palmisano, L. Palmisano, S. Yurdakal, "Partial photocatalytic oxidation of glycerol in $\mathrm{TiO}_{2}$ water suspensions", Catal Tod. 151, p. 21-28, 2010.

[21] D. Liang, J. Gao, J. Wang, P. Chen, Z. Hou, $X$. Zheng, "Selective oxidation of glycerol in a base-free aqueous solution over different sized Pt catalysts", Catal. Commun., 10, p. 15861590, 2009. 